\title{
Drug Resistance to EGFR Inhibitors in Lung Cancer
}

\author{
Osamu Tetsu ${ }^{a, b}$ Matthew J. Hangauer ${ }^{b}$ Janyaporn Phuchareon ${ }^{a, b}$ \\ David W. Eisele $^{a}$ b Frank McCormick ${ }^{b}$ \\ aDepartment of Otolaryngology - Head and Neck Surgery, School of Medicine, University of California San Francisco, \\ and ${ }^{b}$ UCSF Helen Diller Family Comprehensive Cancer Center, School of Medicine, University of California San Francisco, \\ San Francisco, Calif., USA
}

\section{Key Words}

Non-small-cell lung cancer · Epidermal growth factor receptor · Tyrosine kinase inhibitors · Drug resistance . Cancer dormancy · Persister cells · Monotherapy .

Combination therapy $\cdot$ Precision medicine

\section{Abstract}

Background: The discovery of mutations in epidermal growth factor receptor (EGFR) has dramatically changed the treatment of patients with non-small-cell lung cancer (NSCLC), the leading cause of cancer deaths worldwide. EGFR-targeted therapies show considerable promise, but drug resistance has become a substantial issue. Methods: We reviewed the literature to provide an overview of the drug resistance to EGFR tyrosine kinase inhibitors (TKIs) in NSCLC. Results: The mechanisms causing primary, acquired and persistent drug resistance to TKIs vary. Researchers and clinicians, who have used study findings to develop more effective therapeutic approaches, have found that the sequential use of single agents presents a formidable challenge, suggesting that multidrug combinations must be considered. Conclusions: In the era of precision medicine, oncologists should promptly obtain an accurate diagnosis of drug resistance in each patient to be able to design the most relevant combination therapy to overcome patient-specific drug resistance.

(c) 2016 S. Karger AG, Basel

\section{Introduction}

Lung cancer is the leading cause of cancer deaths worldwide $[1,2]$. It is classified into 2 major histologic types based on microscopic features: small-cell lung cancer (SCLC, approx. 15\%) and non-small-cell lung cancer (NSCLC, approx. 85\%). Because NSCLC represents a heterogeneous group of cancers, it is further divided into 3 different pathological subtypes: adenocarcinoma (40\%), squamous-cell carcinoma (25-30\%) and large-cell carcinoma (10-15\%) [3].

These pathological classifications are clinically important, as treatment decisions have depended on tumor histology $[4,5]$. For example, localized NSCLC at an early stage is mainly treated with surgery followed by adjuvant chemotherapy [4]. In contrast, SCLC - even at an early stage - has rarely been treated surgically, as it tends to be more aggressive and spread more rapidly [5]. SCLC is

\section{KARGER}

E-Mail karger@karger.com

www.karger.com/che
(C) 2016 S. Karger AG, Basel

0009-3157/16/0615-0223\$39.50/0
Osamu Tetsu, MD, $\mathrm{PhD}$

UCSF Helen Diller Family Comprehensive Cancer Center School of Medicine, University of California

1450 3rd Street, HD450, San Francisco, CA 94143-0128 (USA)

E-Mail Osamu.Tetsu@ ucsf.edu 
thus usually treated with chemo- and radiotherapy. However, histological distinctions are no longer sufficient for determining treatment plans [6].

Molecular characterization of NSCLCs has provided valuable information for diagnosis, prognosis and treatment [6]. In fact, the discovery of mutations in epidermal growth factor receptor (EGFR) and chromosomal translocations in anaplastic lymphoma kinase (ALK) has dramatically changed the treatment of patients with lung adenocarcinoma [7]. Targeted therapies are currently approved for these abnormalities and show considerable promise $[1,2,7]$. However, drug resistance has become a substantial issue $[1,2,8-11]$.

In this review article, we focus on EGFR-targeted therapy and present an overview of drug resistance in NSCLC. We also discuss therapeutic strategies designed to circumvent drug resistance to EGFR inhibitors.

\section{Methods}

A search of the literature revealed 131 articles (until November $15,2015)$ relevant to drug resistance to EGFR TKIs in NSCLC.

\section{Results}

\section{Molecular Profiling of Lung Adenocarcinomas}

Recent studies have demonstrated that lung adenocarcinomas have recurrent mutations in multiple oncogenes: KRAS (32\%), STK11 (17\%), EGFR (11\%), neurofibromin 1 (NF1, 11\%), BRAF (7\%), MET (7\%), human epidermal growth factor receptor 2 (HER2, 3\%), PTEN (3\%), ROS1 (2\%), ALK (1\%), AKT1 (1\%), RET $(<1 \%), \operatorname{HRAS}(<1 \%)$, NRAS $(<1 \%)$, MEK1 $(<1 \%)$, and PIK3CA $(<1 \%)[12-14]$. With the exception of PIK3CA [14], these mutations are mutually exclusive. Therefore, genetic profiling of NSCLC allows precise molecular classification of the disease. It can also be used to predict the potential efficacy of targeted therapy for each individual with adenocarcinoma [7, 10-13]. In fact, evaluation of gene mutations in EGFR and chromosomal rearrangements of the gene encoding ALK (most commonly resulting in an EML4-ALK fusion gene) are now considered to be the standard of care in advanced-stage pulmonary adenocarcinomas [7]. Intriguingly, EGFR mutations are more prevalent in patients with adenocarcinoma from East Asia who have never smoked or whose habit was light, whereas KRAS mutations are most frequent in Caucasian patients with adenocarcinoma in North America and Europe who have been long-time or heavy smokers $[15,16]$.

\section{Oncogenic Addiction and Targeted Therapy}

The genesis and progression of human cancer involves multiple genetic and epigenetic alterations $[17,18]$. However, the inactivation of a single oncogene can often impair the survival of these altered cells [19]. This phenomenon - known as oncogene addiction - has provided a rationale for molecular-targeted therapy. The use in lung cancer of selective tyrosine kinase inhibitors (TKIs) for EGFR or ALK represents such examples [7]. Here we focus on EGFR TKIs.

EGFR is a receptor tyrosine kinase (RTK) that exists on the cell surface [20]. It belongs to the EGFR/HER family, consisting of 4 members: EGFR, HER2, HER3 and HER4. EGFR becomes activated by overexpression or by ligand-dependent or ligand-independent mechanisms. Ligand-independent activation of the receptor manifests as gain-of-function mutations with the mutant allele showing gene amplification [21,22].

Gefitinib (Iressa) was the first agent designed to target EGFR [22, 23]. It received US Food and Drug Administration (FDA) approval for the treatment of NSCLC, yet its activity was limited to $10-20 \%$ of patients with refractory lung cancer $[1,2]$. In 2002, 2 retrospective cohort studies unexpectedly revealed a correlation between dramatic clinical responses to the TKI and activating EGFR mutations in the catalytic kinase domain of EGFR [21, 22]. Almost similar observations were obtained from treatment with another EGFR TKI, erlotinib (Tarceva), which was approved by the FDA in November 2004 [2, 24-26]. Approximately $85 \%$ of EGFR mutations are either exon 19 deletions (45\%) or the missense mutation L858R (an amino acid substitution at position 858 from leucine to arginine) in exon 21 (41\%) within the kinase domain $[27,28]$.

\section{Heterogeneous Initial Responses to EGFR TKIs in NSCLCs}

A recent randomized, phase- 3 clinical trial with erlotinib found tumor reduction of $>90 \%$ in only $5 \%$ of patients (a complete to near-complete response [29]). The remainder achieved a partial response or maintained stable disease, even though they too had TKI-sensitive EGFR mutations. The heterogeneous nature of this primary response raised questions about its causation - whether this is attributable to resistance inherent in the tumor cells or to acute drug tolerance, or both.

\section{Primary and Acquired Drug Resistance}

Drug resistance is a major obstacle to the success of targeted therapies, including EGFR TKIs [1,2]. Based on 
tumor response to the initial therapy, drug resistance is classified as either primary (also called innate or intrinsic) or acquired (adaptive or secondary) [2, 10]. Patients with primary resistance do not respond at all to treatment, while those with acquired resistance may initially respond completely or partially, only to fail to do so over time. Approximately $10 \%$ of patients harboring TKI-sensitive EGFR mutations show primary resistance to TKIs $[2,10,29]$.

\section{Primary Drug Resistance to EGFR TKIs}

Primary resistance to EGFR TKIs in NSCLCs is mostly associated with wild-type EGFR [30]. It also develops from activated mutations in KRAS or BRAF, or loss of function of the apoptotic protein Bim or some uncommon EGFR mutation [31-34]. More recently, the tumor microenvironment or activation of NF- $\mathrm{kB}$ signaling has also been shown to elicit primary resistance [35-38].

\section{Wild-Type EGFR}

Although erlotinib can prolong survival in patients with unselected NSCLC after first- or second-line chemotherapy [39], the benefit from EGFR TKIs is small in the $90 \%$ of NSCLC patients with wild-type EGFR [30, 40]. A recent clinical trial confirmed this observation. Only $3 \%$ of patients harboring wild-type EGFR had a partial response to erlotinib; in the remainder, docetaxel (Taxotere) was more effective [41].

\section{KRAS and BRAF Mutations}

EGFR, KRAS and BRAF mutations are mutually exclusive [14]. In approximately $30 \%$ of NSCLCs, activating KRAS mutations are observed at codons 12 or 13 and are considered to constitute a negative predictor for EGFRtargeted therapies [31]. Despite EGFR inhibition, KRAS mutations constitutively activate downstream MAPK signaling, presenting another mechanism that contributes to primary resistance.

Likewise, 7\% of NSCLCs harbor mutations in BRAF. The most common change in BRAF is the V600E mutation (an amino acid substitution at position 600 from valine to glutamic acid), which confers resistance to EGFR TKIs but shows increased sensitivity to specific smallmolecule V600E inhibitors as well as to MEK inhibitors [32].

\section{Bim Polymorphism}

Bim is a BH3-only protein, which is essential for apoptosis and caspase induction in EGFR-mutated NSCLC cells [42-44]. Thus, a reduction of Bim expression in

Drug Resistance to EGFR Inhibitors in

Lung Cancer
NSCLC may cause drug resistance to TKIs. A recent report demonstrated that genetic polymorphism generates alternative splicing variants of Bim protein lacking the $\mathrm{BH} 3$ domain, which is sufficient to confer primary resistance to TKIs in NSCLCs harboring EGFR mutations [33].

\section{Various EGFR Mutations}

The most common activating EGFR mutations (85\%) are either L858R or exon 19 deletions, which confer drug sensitivity to EGFR TKIs [27, 34]. However, less common EGFR mutations also exist. Among them, G719X in exon 18 (a substitution at position 719 from glycine to some other amino acid; 3\%) and L861Q in exon 21 (an amino acid substitution at position 861 from leucine to glutamic acid; 2\%) appear sensitive to TKIs [27, 34].

However, not all EGFR mutations are equally sensitive [27]; some cause TKI resistance. For example, small insertions or duplications in exon 20, which account for 5-10\% of EGFR mutations, are associated with primary resistance, except for the rare case with EGFR exon 20 insertion A763_Y764insFQEA [45, 46].

A recent study demonstrated that, although the vast majority of cancer cells harbor classic activating EGFR mutations, the EGFR TKI resistance conferring the T790M EGFR mutation (an amino acid substitution from threonine to methionine at position 790) can be found within rare cells in primary tumors. Subsequent clonal selection of these preexisting EGFR TKI-resistant cells during EGFR TKI treatment may contribute to drug resistance $[47,48]$.

\section{Tumor Microenvironment}

The latest studies have demonstrated that RTK ligands secreted through paracrine, autocrine and endocrine mechanisms in the tumor microenvironment are also important determinants of primary therapeutic responses to anticancer kinase inhibitors [35-37]. Indeed, hepatocyte growth factor (HGF), fibroblast growth factor (FGF) and neuregulin 1 (NRG1) confer primary drug resistance to a large number of cancer cell lines by activating RTKs and thus stimulating either the Ras/MAPK or PI3K/AKT prosurvival pathway or both [35]. HGF-mediated activation of the RTK MET is suspected as the most important cause of primary resistance to anticancer agents [35-37].

\section{Activation of NF- $\kappa \mathrm{B}$ Signaling}

$\mathrm{NF}-\kappa \mathrm{B}$ signaling activation was recently identified as a mechanism of primary resistance to EGFR TKI [38]. Low expression of $\mathrm{I} \kappa \mathrm{B}$, the $\mathrm{NF}-\kappa \mathrm{B}$ inhibitor, was a predictor of 
a poor clinical outcome in patients treated with erlotinib [38]. Thus, combined therapy with EGFR TKI and an inhibitor of NF- $\mathrm{KB}$ signaling can enhance primary responses in a subset of NSCLCs harboring EGFR mutations.

\section{Acquired Drug Resistance to EGFR TKIs}

Acquired resistance to EGFR TKIs develops after an average of 1 year of continuous treatment [1,2]. A clinical definition has recently been proposed by Jackman et al. [49]. According to their criteria, the tumor should harbor TKI-sensitive EGFR mutations such as L858R or exon 19 deletions, should have responded either partially or completely (unless stable disease has been present for more than 6 months) and have demonstrated systemic progression.

Four different mechanisms of acquired drug resistance to EGFR TKIs have been reported [1,2]: (1) EGFR target alterations in the drug target itself (such as T790M secondary mutation $[30,45]$ ), which can nullify the activity of gefitinib or erlotinib without changing the RTK activity, (2) activation of alternative signaling pathways to bypass the EGFR inhibition (such as amplification of RTK MET $[50,51]$ or HER2 [52, 53], activation of another oncogenic driver, BRAF [54] or inactivation of the tumor suppressors PTEN [55, 56] or NF1 [57]), (3) a lineage switch through histological transformation from NSCLC to SCLC [58-60] or epithelial-mesenchymal transition (EMT) [61-63] and (4) intratumor heterogeneity [64].

\section{T790M and Other Secondary EGFR Mutations}

Acquired resistance to gefitinib and erlotinib is predominantly mediated by the development of the T790M EGFR secondary mutation, which occurs in $50-65 \%$ of patients with the EFGR mutation and TKI resistance [1, $2,8,30,45]$. Threonine 790 is the gatekeeper residue in EGFR, lies within the ATP-binding pocket of EGFR and influences drug effectiveness [65]. In agreement with this notion, a recent report demonstrated that the T790M mutation in EGFR confers drug resistance by increasing the affinity for ATP [66]. In addition, a further chromosomal amplification of the gene locus may enhance the inhibitory effect of T790M [67].

Gatekeeper mutations can be a common mechanism of acquired drug resistance to targeted therapies in cancer [68]. In fact, analogous mutations are reported in malignances exposed to various TKIs: imatinib-resistant T315I BCR-ABL fusion kinase in chronic myelogenous leukemia (CML) [69], imatinib-resistant T670I KIT in gastrointestinal stromal tumor (GIST) [70] and crizotinib-resistant L1196M ALK fusion gene in NSCLC [71].
Other rarer TKI-induced EGFR mutations, constituting $<10 \%$ of all secondary substitutions in EGFR, have been reported: L747S [42], D761Y [72] and T854A [73]. Although these non-T790M mutations have been associated with acquired resistance to TKIs, their drug-resistant mechanism is not yet clear [74].

\section{Activation of Alternative Pathways}

Recently, a common mechanism of acquired resistance to EGFR TKIs has been reported as a result of an RTK switch, such as amplification of MET $[50,51]$ or HER2 [52, 53] or activation of HER3 [75, 76], insulin-like growth factor 1 receptor (IGF-1R) [77, 78] or fibroblast growth factor receptor 1 (FGFR1) [79, 80].

MET Amplification. Amplification of the MET gene is identified in 5-20\% of EGFR-mutated NSCLCs with acquired drug resistance to EGFR TKIs [50]. Amplified MET specifically makes a heterodimeric complex with HER3, one of 4 members of the EGFR kinase family, and activates the PI3K/AKT pathway to bypass EGFR inhibition [50]. MET amplification is not mutually exclusive with the T790M secondary mutation; indeed, the latter is seen in 50\% [51]. Thus, it is possible to conjecture that MET-amplified clones are selected after exposure to EGFR TKIs and then acquire the T790M mutation. In fact, MET amplification is found in $2-4 \%$ of previously untreated EGFR-mutated NSCLCs [51]. In any case, the population harboring activating EGFR mutations and MET amplification can achieve a clinical benefit from combined therapy with EGFR and MET inhibitors, as shown in a recent phase-III clinical trial [81].

HER2 Amplification. HER2 is amplified in $12 \%$ of tumors with acquired resistance, but the gene amplification is found in only $1 \%$ of untreated lung adenocarcinoma $[52,53]$. No mutations in HER2 are found in this population. Importantly, HER2 amplification and T790M mutation occur in a mutually exclusive manner. These observations clearly suggest that HER2 amplification is an alternative mechanism of drug resistance to EGFR TKIs [2]. Indeed, HER2 is a potential therapeutic target because its overexpression or knockdown can confer, respectively, resistance or sensitivity to TKIs in NSCLC cells [53].

HER3 Activation. HER3 is activated independently of MET amplification in NSCLCs, and may contribute to acquired drug resistance to EGFR TKI $[75,76]$. HER3 lacks several catalytically important residues and is thought to be an inactive pseudokinase [82]. However, it can form a heterodimeric complex with EGFR/HER2 to stimulate downstream cell signaling $[83,84]$ and can be 
activated by its ligand NRG1 through an autocrine mechanism [85].

In NSCLC cells, HER3 couples with EGFR to activate the PI3K/AKT pathway in gefitinib-sensitive NSCLC cell lines, but not in gefitinib-resistant lines, suggesting that NRG1-bound HER3 may predominantly dimerize with RTKs other than EGFR to promote acquired resistance to TKIs [76]. This mechanism may provide a rationale for the combined treatment of NSCLC patients with erlotinib and patritumab, an anti-HER3 monoclonal antibody [86].

IGF-1R Activation. IGF-1R has also been proposed to have a role in mediating acquired drug resistance to EGFR TKIs [77, 78], and, in fact, was reported as a biomarker for resistance to the TKI in NSCLC [78]. Unfortunately, data are conflicting: IGF-1R expression has been significantly associated with longer survival in NSCLC patients treated with gefitinib [87]. Further studies are warranted.

FGFR1 Activation. FGFR1 is activated by its ligand fibroblast growth factor (FGF) 2 through an autocrine mechanism and confers acquired drug resistance in NSCLC cells $[79,80]$.

BRAF Mutations. Mutations occurring in other driver oncogenes may also affect acquired drug resistance to EGFR TKIs. BRAF, but not KRAS, mutations are found in TKI-resistant NSCLC tumors, although their frequency is very low [54].

Loss of PTEN Expression. PTEN is a tumor suppressor gene controlling the PI3K/AKT pathway [88], and its mutation or loss of expression has been reported as a potential mechanism of acquired drug resistance $[55,56]$.

Reduced NF1 Expression. NF1 is a negative regulator of the Ras oncogene through stimulation of Ras GTPase activity [89]. TKI-induced low levels of NF1 expression have been associated with primary and acquired resistance to EGFR TKIs in NSCLC patients [57]. Treatment of NF1-deficient lung cancers with MEK inhibitors has restored sensitivity to TKIs, suggesting that combination therapy with MEK and EGFR inhibitors may have a clinical benefit $[57,90]$.

\section{Histologic Transformation}

In a rare phenomenon of acquired drug resistance, 2 lineage switches have been reported: histologic transformation of EGFR-mutated NSCLC to SCLC [58-60] and EMT [61-63]. The former has been reported in $2-14 \%$ of patients with acquired resistance to EGFR TKI [58-60]. These new SCLCs continued to harbor the initial activating EGFR mutations and were highly sensitive to the chemotherapy regimens for SCLC [60].

Drug Resistance to EGFR Inhibitors in

Lung Cancer
The lineage switch from NSCLC adenocarcinoma to SCLC was recently reported to involve the loss of RB1 (retinoblastoma 1) and EGFR proteins [91]. Actually, primary SCLCs are known to have a high prevalence of inactivating mutations in RB1 and TP53 [92]. In contrast, EGFR mutations and gene amplifications are rarely found in sporadic SCLCs [92]. Thus, the loss of RB1 expression can be the most likely scenario for lineage switching [91]. The study also suggested that NSCLC and SCLC may share the same cells of origin [93]. Alveolar type II cells might have the potential [94], but further studies are required.

EMT is a cellular mechanism critical for normal development, wound healing and cancer metastasis [95]. In the process of EMT, cells undergo a lineage switch from an epithelial to a mesenchymal phenotype, which causes a loss of cellular polarity, resulting in high motility and increased invasion capability [95]. EMT induction can be triggered by various cell signals, including TGF-beta and Notch-1, and may confer acquired drug resistance [61, 62]. A recent study demonstrated that the mechanisms leading to EMT in TKI-treated patients may involve the activation of AXL RTK [63]. AXL overexpression has been found in $20 \%$ of NSCLC samples with progressive disease after treatment with EGFR TKI. However, how EMT promotes TKI drug resistance remains unclear, and additional investigation is warranted.

\section{Intratumor Heterogeneity}

Intratumor heterogeneity may also account for drug resistance [64]; for example, activating EGFR mutations and MET amplification were shown to coexist in a minor subset of cells in previously untreated TKI-sensitive NSCLC [51]. Subsequent clonal selection of the doubly positive cells could result in acquired drug resistance by affecting additional genomic alterations such as T790M EGFR [51].

\section{Cancer Dormancy and Acquired Drug Resistance}

The origin of resistant cells remains to be elucidated, but they must arise from surviving populations [96-98]. These cells lie temporarily dormant or quiescent as a means of circumventing the effects of the given therapy, but eventually regain their proliferative capacity [99]. The dormant cells resist chemotherapy because they do not divide until the environment is favorable to resume cell proliferation [100]. In the clinical setting, cancer dormancy is observed as a 'grace period' after treatment [101]: the signs and symptoms of cancer have disappeared, but the patient occasionally carries surviving tumor cells in local and distant bodily regions. 
Drug-Tolerant Persister Cells

In a recent study by Sharma et al. [102], cultured cells from various cancer tissues remained after targeted or cytotoxic chemotherapy. This phenomenon can affect up to $10 \%$ of a genetically homogeneous drug-sensitive population; these drug-tolerant cells are thus far more numerous than might be expected from resistance based on the acquisition of de novo genetic mutations. Importantly, however, this was shown to be reversible, which supports the notion of a nonmutational mechanism.

In an analogy to microbial persister cells, these nonmutational drug-resistant cells were defined as drug-tolerant persisters. In 1942, in the study by Hobby et al. [103], Gladys Hobby first described the phenomenon of bacterial persistence, whereby penicillin was found to kill the vast majority of cultured streptococcal cells, but $1 \%$ remained intact [104]. These residual cells were characterized in 1944 by Joseph Bigger [105] as 'bacterial persisters'.

In lung cancers, drug-tolerant persisters emerge during treatment as a subset of the cells within primary tumors [96, 102]. Although initially quiescent, persister cells can soon begin to propagate in the presence of EGFR TKIs, becoming drug-tolerant, expanded persisters. These may be cancer stem cells or mesenchymal cells because of their ability to escape the effects of drug treatment by becoming quiescent [102]. Epigenetic mechanisms have been proposed to explain this distinct lineageswitching [102]. However, in our investigation of the small TKI-tolerant subset of NSCLC cells, we could not detect known lung cancer stem cell markers, nor did we uncover expression changes in mesenchymal cell markers [97, 98]. This suggested that a different mechanism could also cause the quiescent status of NSCLC cells after EGFR inhibition.

\section{Drug Resistance of Dormant NSCLC Cells to EGFR \\ TKIs}

As mentioned above, we recently studied the mechanism by which a small subset of cells remains viable after EGFR inhibition, despite cell death in the vast majority [96-98, 106, 107]. Our study demonstrated that EGFR inhibition in lung cancer cells generates a drug-tolerant subpopulation by blocking AKT activity and thus inactivating Ets-1 function (fig. 1). The remaining cells enter a dormant, nondividing, quiescent state (G0/G1 arrest) because of the inhibited transactivation of the Ets-1 target genes cyclins D1, D3 and E2. Moreover, Ets-1 inactivation inhibits the transcription of dual-specificity phosphatase 6 (DUSP6), a negative regulator specific for ERK1/2. As a result, ERK1/2 is activated, which then combines with c-

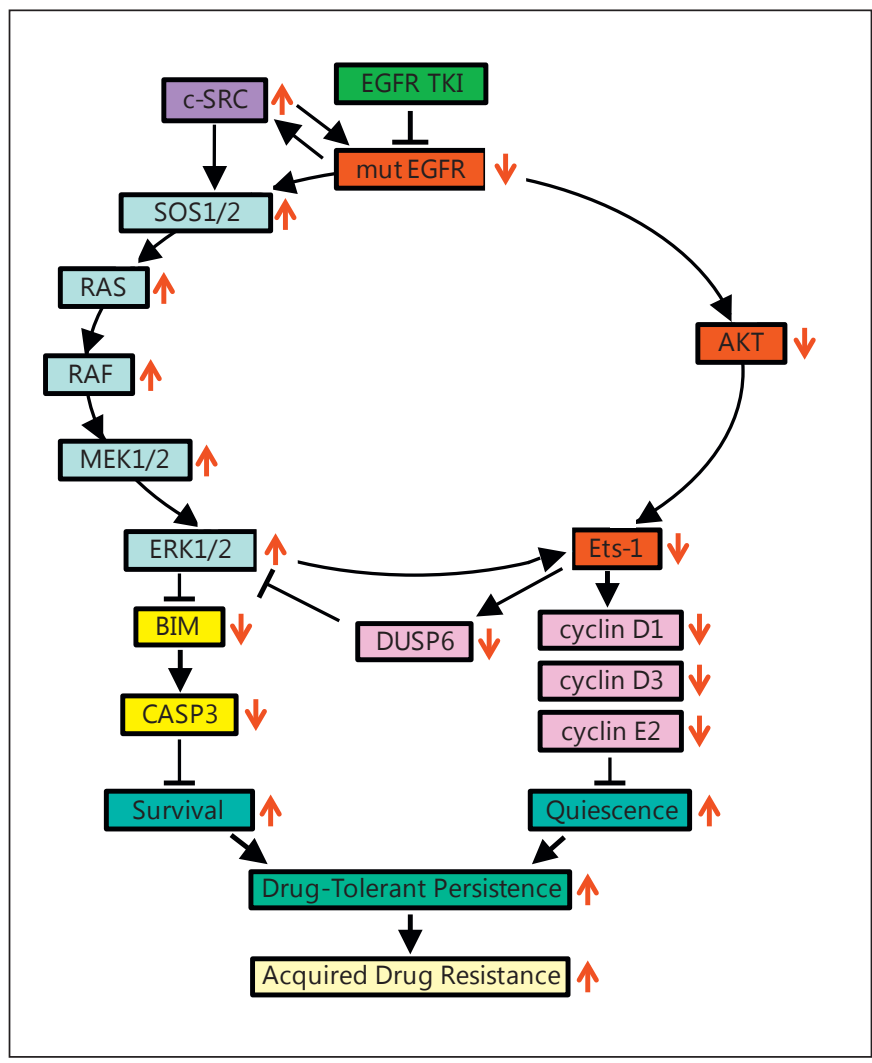

Fig. 1. Schematic of the molecular mechanism of EGFR inhibition and drug resistance in EGFR-mutated NSCLC cells. Increases and decreases in activity/ expression of signaling molecules or biological outcomes resulting from EGFR inhibition are indicated by red arrows.

Src to renew the activation of the Ras/MAPK pathway, causing increased cell survival by accelerating the turnover of Bim protein. These observations may explain why a small subset of quiescent persister cells can tolerate TKIs, which leads to acquired drug resistance.

\section{Overcoming Drug Resistance to EGFR Inhibitors}

Among the numerous therapeutic investigations to improve patient outcomes $[2,8]$, the focus has narrowed to T790M EGFR, the most common mechanism of drug resistance to gefitinib and erlotinib. Below is an overview of the past decade's battles to overcome T790M-mediated resistance.

Retreatment with the Same TKI after a Treatment Interruption

Treating patients with other anticancer agents occasionally restores sensitivity to EGFR TKIs (fig. 2a) [108]. 
Fig. 2. Different strategies to overcome drug resistance to EGFR inhibitors. a Retreatment with the same TKI after a treatment interruption. Resistant tumors are often composed of mixed populations of sensitive and resistant cancer cells. A chemotherapy regimen that interrupts the TKI therapy for a period of time, i.e. a 'drug holiday', may effect a restoration of the TKI's efficacy. b Administration of T790M-specific EGFR TKIs. The third-generation TKIs inhibit both mutations of EGFR activation and resistance. Early-phase studies demonstrated promising response rates in tumors with acquired T790M EGFR mutation. Unfortunately, acquired resistance developed in EGFR with or without the T790M mutation. c Targeting drug-tolerant persister cells. The drug-tolerant persister cells could be a therapeutic target, as reduction of this subset may prevent emergent resistance to EGFR inhibitors. We and other study groups recently proposed a combined EGFR and MEK inhibition therapy.

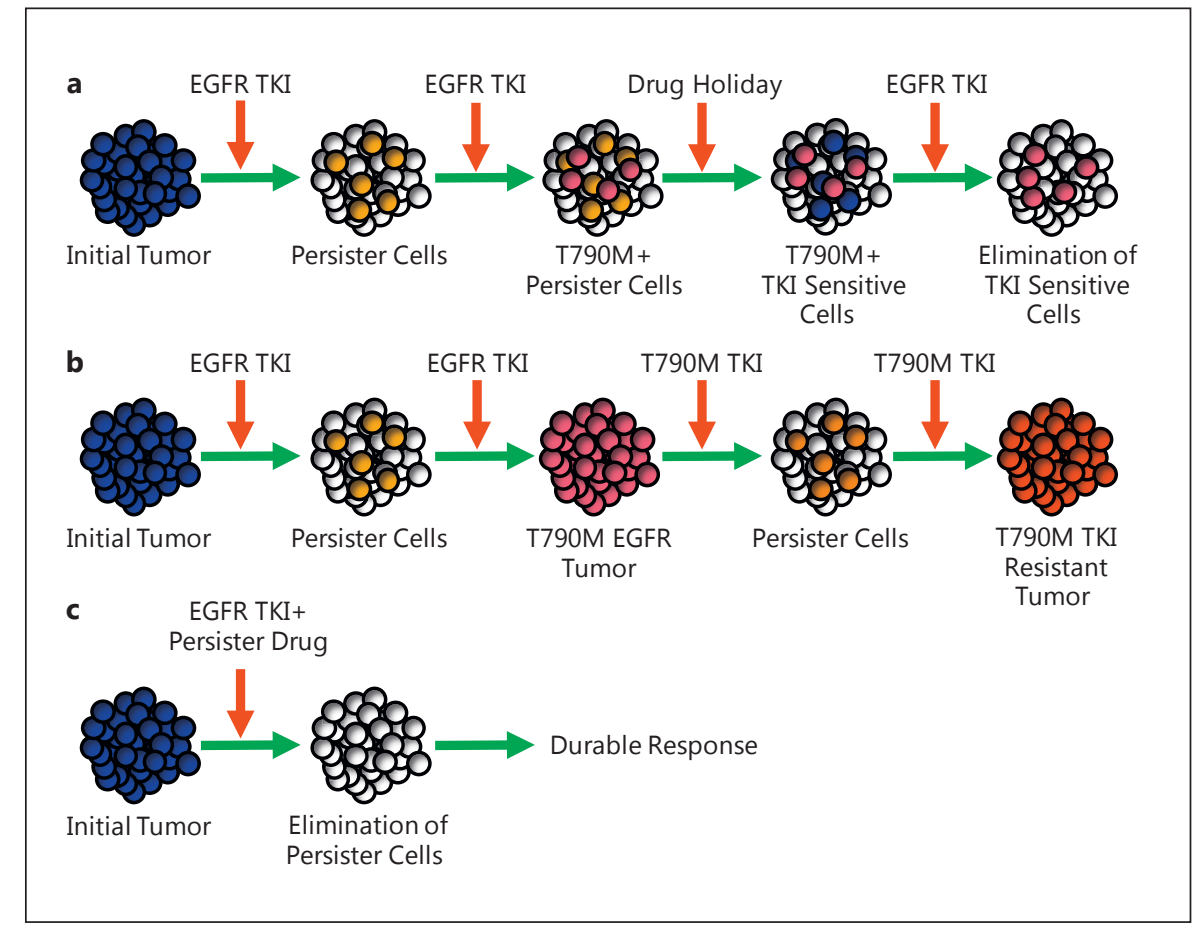

A chemotherapy regimen that interrupts the TKI therapy for a period of time, i.e. a 'drug holiday', may effect a restoration of the TKI's efficacy [8]. Nevertheless, there is a risk that dormant cancer cells might rapidly expand in some cases when the TKI treatment is suddenly stopped $[99,100]$.

\section{T790M-Specific EGFR TKIs}

In contrast to first-generation reversible EGFR TKIs (gefitinib and erlotinib), second-generation TKIs such as afatinib (Gilotrif) [109], dacomitinib (PF-00299804) [110] and neratinib (HKI-272) [111] bind irreversibly to EGFR and other EGFR family members, including HER2 [8]. These agents were thus thought to be effective for patients with the T790M EGFR drug-resistant mutation $[112,113]$. However, early-phase clinical trials found no objective response in this population [114-116].

In contrast, the third-generation TKIs, AZD9291 [117], rociletinib (CO-1686) [118] and WZ4002 [119], inhibit both mutations of EGFR activation and resistance, while they have a modest activity with wild-type EGFR (fig. 2b) [8]. In early-phase studies, AZD9291 and rociletinib demonstrated promising response rates (approx. $60 \%$ ) in tumors with an acquired T790M EGFR mutation $[117,120,121]$. Unfortunately, acquired resistance to both of these developed in EGFR with or without the
T790M mutation, demonstrating intratumor heterogeneity [122-126].

Of the third-site EGFR mutations (i.e. L718Q, L844V and C797S [125]), C797S was found in approximately $40 \%$ of AZD9291-resistant T790M-positive tumors. L858R, T790M and C797S EGFR mutation-positive cells showed a partial sensitivity to cetuximab, a monoclonal antibody against EGFR [125]. More recently, additional mechanisms of drug resistance to AZD9291 have been reported, i.e. the loss of the T790M mutation and EGFR gene amplification and also SCLC histologic transformation [122]. These findings suggest that stepwise monotherapies represent a formidable challenge in drug-resistant cells and that simultaneous multidrug combination therapies should be considered [127].

\section{Targeting Drug-Tolerant Persister Cells}

Drug-tolerant persister cells could be a therapeutic target, as reduction of this subset may prevent emergent resistance to EGFR inhibitors (fig. 2c) [97, 98]. Drug-tolerant cells were previously shown to be sensitive to the histone deacetylase (HDAC) inhibitor [102]. However, the combined therapy of erlotinib and entinostat, an HDAC inhibitor, did not improve clinical outcome [128].

Recently, we proposed a combined EGFR and MEK inhibition therapy $[96-98,106,107]$. Our study demon- 
Table 1. Mechanisms of drug resistance to EGFR TKIs

\begin{tabular}{lll}
\hline Primary resistance & Acquired resistance & Persistent resistance \\
\hline Wild-type EGFR [30, 41] & Target alterations & AKT inhibition [96] \\
KRAS mutation [31] & T790M EGFR [65] & Epigenetics [102] \\
BRAF mutation [32] & L747S [42], D761Y [72] or T854A [73] EGFR & Activation of alternative pathways \\
Bim polymorphism [33] & MET amplification [50, 81] \\
EGFR exon 20 insertions or duplications [45, 46] & HER2 amplification [52, 53] \\
T790M EGFR [47, 48] & HER3 activation [75, 76] \\
Tumor microenvironment [35-37] & IGF-1R activation [77, 78] \\
NF- $\kappa B$ signaling activation [38] & FGF1 activation [79, 80] \\
& BRAF mutation [54] \\
& PTEN loss [55, 56] \\
& NF1 reduction [57] \\
& Histologic transformation \\
& SCLC [58-60] & EMT [61-63] \\
& Intratumor heterogeneity \\
& [64] \\
\hline
\end{tabular}

Table 2. Targeted therapy: EGFR TKIs

\begin{tabular}{lll}
\hline 1st-generation & 2nd-generation & 3rd-generation \\
\hline Gefitinib [23, 24] & Afatinib [109] & AZD9291 [117] \\
Erlotinib [24-26] & Dacomitinib [110] & Rociletinib [118] \\
& Neratinib [111] & WZ4002 [119] \\
\hline
\end{tabular}

strated that the addition of an MEK inhibitor enhances programmed cell death by rewiring apoptotic signaling after EGFR inhibition in persister cells. Therefore, to decrease the probability of emergent resistance to EGFR TKIs in NSCLCs, combined TKI and MEK inhibitor treatment should be considered. A recent report from another laboratory has also proposed this novel therapy, which is thought to be effective not only in TKI-sensitive activating EGFR mutations but also in the acquired resistance with the T790M second-site EGFR mutation [129]. Interestingly, a separate report showed that ERK1/2 reactivation accompanied DUSP6 reduction after L858R/ T790M EGFR-selective inhibition in gefitinib-resistant cells [130]. Thus, a clear rationale for combined treatment exists, regardless of whether the drug resistance is persistent or acquired. A randomized, double-blind trial is necessary before this novel therapy can be integrated into the management of EGFR-mutated NSCLCs in the clinical setting.

\section{Conclusions}

Over the past decade, EGFR-targeted therapies have dramatically changed the treatment of patients with lung adenocarcinoma. However, drug resistance has become a substantial issue. Recent studies have identified the mechanisms of primary, acquired and persistent drug resistance to TKIs (table 1) and researchers and clinicians have used these findings to develop therapeutic approaches (table 2). However, the stepwise use of single agents presents a formidable challenge. This suggests that researchers and clinicians should consider multidrug combinations to overcome drug resistance. In this era of precision medicine, oncologists must promptly obtain an accurate diagnosis of drug resistance during the individual clinical course to design the most relevant combination to overcome the patient-specific drug resistance in this population [131].

\section{Acknowledgements}

This work was supported by grants from the Joan and Irwin Jacobs Fund of the Jewish Community Foundation to O.T. and the National Cancer Institute (1U01CA168370-01) to F.M. 


\section{References}

-1 Pao W, Chmielecki J: Rational, biologically based treatment of EGFR-mutant non-smallcell lung cancer. Nat Rev Cancer 2010;10: 760-774.

$\checkmark 2$ Chong CR, Janne PA: The quest to overcome resistance to EGFR-targeted therapies in cancer. Nat Med 2013;19:1389-1400.

3 American Cancer Society: What is non-small cell lung cancer? (last medical review: 08/15/2014, last revised: 03/04/2015) http:// www.cancer.org/cancer/lungcancer-nonsmallcell/detailedguide/non-small-cell-lungcancer-what-is-non-small-cell-lung-cancer.

$\checkmark 4$ Crino L, Weder W, van Meerbeeck J, Felip E; ESMO Guidelines Working Group: Early stage and locally advanced (non-metastatic) non-small-cell lung cancer: ESMO clinical practice guidelines for diagnosis, treatment and follow-up. Ann Oncol 2010;21(suppl 5):v103-v115.

$>5$ Veronesi G, Bottoni E, Finocchiaro G, Alloisio M: When is surgery indicated for smallcell lung cancer? Lung Cancer 2015;90:582589.

6 Neal JW: Histology matters: individualizing treatment in non-small cell lung cancer. Oncologist 2010;15:3-5.

7 Thomas A, Liu SV, Subramaniam DS, Giaccone G: Refining the treatment of NSCLC according to histological and molecular subtypes. Nat Rev Clin Oncol 2015;12:511-526.

8 Ohashi K, Maruvka YE, Michor F, Pao W: Epidermal growth factor receptor tyrosine kinase inhibitor-resistant disease. J Clin Oncol 2013;31:1070-1080.

$>9$ Camidge DR, Pao W, Sequist LV: Acquired resistance to TKIs in solid tumours: learning from lung cancer. Nat Rev Clin Oncol 2014; 11:473-481.

10 Cortot AB, Janne PA: Molecular mechanisms of resistance in epidermal growth factor receptor-mutant lung adenocarcinomas. Eur Respir Rev 2014;23:356-366.

$>11$ Kuo SC, Hsu PC, Chen CH, Yu CT, Wang CL, 23 Chung FT, Lin SM, Lo YL, Chen TC, Liu CY, Yang CT: Overall response to first-line tyrosine kinase inhibitor and second-line chemotherapy is predictive of survival outcome in epidermal growth factor receptor-mutated adenocarcinoma. Chemotherapy 2014;60: 201-210.

-12 Pao W, Girard N: New driver mutations in non-small-cell lung cancer. Lancet Oncol 2011;12:175-180.

$>13$ Oxnard GR, Binder A, Janne PA: New targetable oncogenes in non-small-cell lung cancer. J Clin Oncol. 2013;31:1097-1104.

14 Cancer Genome Atlas Research Network: Comprehensive molecular profiling of lung adenocarcinoma. Nature 2014;511:543-550.
15 Shigematsu H, Lin L, Takahashi T, Nomura M, Suzuki M, Wistuba II, Fong KM, Lee H, Toyooka S, Shimizu N, Fujisawa T, Feng Z, Roth JA, Herz J, Minna JD, Gazdar AF: Clinical and biological features associated with epidermal growth factor receptor gene mutations in lung cancers. J Natl Cancer Inst 2005; 97:339-346.

16 Riely GJ, Kris MG, Rosenbaum D, Marks J, Li A, Chitale DA, Nafa K, Riedel ER, Hsu M, Pao W, Miller VA, Ladanyi M: Frequency and distinctive spectrum of KRAS mutations in never-smokers with lung adenocarcinoma. Clin Cancer Res 2008;14:5731-5734.

17 Hanahan D, Weinberg RA: Hallmarks of cancer: the next generation. Cell 2011;144:646674.

18 Vogelstein B, Papadopoulos N, Velculescu VE, Zhou S, Diaz LA Jr, Kinzler KW: Cancer genome landscapes. Science 2013;339:15461558.

19 Felsher DW: Reversibility of oncogene-induced cancer. Curr Opin Genet Dev 2004;14: 37-42.

20 Yarden Y: The EGFR family and its ligands in human cancer. Signaling mechanisms and therapeutic opportunities. Eur J Cancer 2001; 37(suppl 4):S3-S8.

21 Paez JG, Janne PA, Lee JC, Tracy S, Greulich H, Gabriel S, Herman P, Kaye FJ, Lindeman N, Boggon TJ, Naoki K, Sasaki H, Fujii Y, Eck MJ, Sellers WR, Johnson BE, Meyerson M: EGFR mutations in lung cancer: correlation with clinical response to gefitinib therapy. Science 2004;304:1497-1500.

22 Lynch TJ, Bell DW, Sordella R, Gurubhagavatula $S$, Okimoto RA, Brannigan BW, Harris PL, Haserlat SM, Supko JG, Haluska FG, Louis DN, Christiani DC, Settleman J, Haber DA: Activating mutations in the epidermal growth factor receptor underlying responsiveness of non-small-cell lung cancer to gefitinib. N Engl J Med 2004;350:2129-2139.

3 Baselga J, Averbuch SD: ZD1839 ('Iressa') as an anticancer agent. Drugs 2000;60(suppl 1):33-40.

24 Juchum M, Gunther M, Laufer SA: Fighting cancer drug resistance: opportunities and challenges for mutation-specific EGFR inhibitors. Drug Resist Updat 2015;20:12-28.

25 Moyer JD, Barbacci EG, Iwata KK, Arnold L, Boman B, Cunningham A, DiOrio C, Doty J, Morin MJ, Moyer MP, Neveu M, Pollack VA, Pustilnik LR, Reynolds MM, Sloan D, Theleman A, Miller P: Induction of apoptosis and cell cycle arrest by CP-358,774, an inhibitor of epidermal growth factor receptor tyrosine kinase. Cancer Res 1997;57: 4838-4848.

26 Cohen MH, Johnson JR, Chen YF, Sridhara R, Pazdur R: FDA drug approval summary: erlotinib (Tarceva) tablets. Oncologist 2005;10: 461-466.
27 Cheng L, Alexander RE, Maclennan GT, Cummings OW, Montironi R, Lopez-Beltran A, Cramer HM, Davidson DD, Zhang S: Molecular pathology of lung cancer: key to personalized medicine. Mod Pathol 2012;25: 347-369.

28 Janne PA, Johnson BE: Effect of epidermal growth factor receptor tyrosine kinase domain mutations on the outcome of patients with non-small cell lung cancer treated with epidermal growth factor receptor tyrosine kinase inhibitors. Clin Cancer Res 2006;12: 4416s-4420s.

-29 Rosell R, Carcereny E, Gervais R, et al; Spanish Lung Cancer Group in collaboration with Groupe Français de Pneumo-Cancerologie and Associazione Italiana Oncologia Toracica: Erlotinib versus standard chemotherapy as first-line treatment for European patients with advanced EGFR mutation-positive nonsmall-cell lung cancer (EURTAC): a multicentre, open-label, randomised phase 3 trial. Lancet Oncol 2012;13:239-246.

30 Gazdar AF: Activating and resistance mutations of EGFR in non-small-cell lung cancer: role in clinical response to EGFR tyrosine kinase inhibitors. Oncogene 2009;28(suppl 1):S24-S31.

31 Massarelli E, Varella-Garcia M, Tang X, Xavier AC, Ozburn NC, Liu DD, Bekele BN, Herbst RS, Wistuba II: KRAS mutation is an important predictor of resistance to therapy with epidermal growth factor receptor tyrosine kinase inhibitors in non-small-cell lung cancer. Clin Cancer Res 2007;13:2890-2896.

32 Ohashi K, Sequist LV, Arcila ME, Moran T, Chmielecki J, Lin YL, Pan Y, Wang L, de Stanchina E, Shien K, Aoe K, Toyooka S, Kiura K, Fernandez-Cuesta L, Fidias P, Yang JC, Miller VA, Riely GJ, Kris MG, Engelman JA, Vnencak-Jones CL, Dias-Santagata D, Ladanyi M, Pao W: Lung cancers with acquired resistance to EGFR inhibitors occasionally harbor BRAF gene mutations but lack mutations in KRAS, NRAS, or MEK1. Proc Natl Acad Sci USA 2012;109:E2127-E2133.

$33 \mathrm{Ng}$ KP, Hillmer AM, Chuah CT, et al: A common BIM deletion polymorphism mediates intrinsic resistance and inferior responses to tyrosine kinase inhibitors in cancer. Nat Med 2012;18:521-528.

34 Beau-Faller M, Prim N, Ruppert AM, NanniMetellus I, Lacave R, Lacroix L, Escande F, Lizard S, Pretet JL, Rouquette I, de Cremoux P, Solassol J, de Fraipont F, Bieche I, Cayre A, Favre-Guillevin E, Tomasini P, Wislez M, Besse B, Legrain M, Voegeli AC, Baudrin L, Morin F, Zalcman G, Quoix E, Blons H, Cadranel J: Rare EGFR exon 18 and exon 20 mutations in non-small-cell lung cancer on 10117 patients: a multicentre observational study by the French ERMETIC-IFCT network. Ann Oncol 2014;25:126-131. 
-35 Wilson TR, Fridlyand J, Yan Y, Penuel E, Burton L, Chan E, Peng J, Lin E, Wang Y, Sosman J, Ribas A, Li J, Moffat J, Sutherlin DP, Koeppen $H$, Merchant M, Neve R, Settleman J: Widespread potential for growth-factor-driven resistance to anticancer kinase inhibitors. Nature 2012;487:505-509.

- 36 Straussman R, Morikawa T, Shee K, BarzilyRokni M, Qian ZR, Du J, Davis A, Mongare MM, Gould J, Frederick DT, Cooper ZA, Chapman PB, Solit DB, Ribas A, Lo RS, Flaherty KT, Ogino S, Wargo JA, Golub TR: Tumour micro-environment elicits innate resistance to RAF inhibitors through HGF secretion. Nature 2012;487:500-504.

- 37 Kentsis A, Reed C, Rice KL, Sanda T, Rodig SJ, Tholouli E, Christie A, Valk PJ, Delwel R, Ngo V, Kutok JL, Dahlberg SE, Moreau LA, Byers RJ, Christensen JG, Vande Woude G, Licht JD, Kung AL, Staudt LM, Look AT: Autocrine activation of the MET receptor tyrosine kinase in acute myeloid leukemia. Nat Med 2012;18:1118-1122.

- 38 Bivona TG, Hieronymus H, Parker J, Chang K, Taron M, Rosell R, Moonsamy P, Dahlman K, Miller VA, Costa C, Hannon G, Sawyers CL: FAS and NF- $\kappa B$ signaling modulate dependence of lung cancers on mutant EGFR. Nature 2011;471:523-526.

- 39 Shepherd FA, Rodrigues Pereira J, Ciuleanu T, Tan EH, Hirsh V, Thongprasert S, Campos D, Maoleekoonpiroj S, Smylie M, Martins R, van Kooten M, Dediu M, Findlay B, Tu D, Johnston D, Bezjak A, Clark G, Santabarbara P, Seymour L; National Cancer Institute of Canada Clinical Trials Group: Erlotinib in previously treated non-small-cell lung cancer. N Engl J Med 2005;353:123-132.

-40 Kang EJ, Min KH, Hur GY, Lee SY, Shim JJ, Kang KH, Oh SC, Seo JH, Kim JS: Comparison of the Efficacy between pemetrexed plus platinum and non-pemetrexed plus platinum as first-line treatment in patients with wildtype epidermal growth factor receptor nonsquamous non-small cell lung cancer: a retrospective analysis. Chemotherapy 2015;61:4150.

-41 Garassino MC, Martelli O, Broggini M, Farina G, Veronese S, Rulli E, Bianchi F, Bettini A, Longo F, Moscetti L, Tomirotti M, Marabese M, Ganzinelli M, Lauricella C, Labianca R, Floriani I, Giaccone G, Torri V, Scanni A, Marsoni S: Erlotinib versus docetaxel as second-line treatment of patients with advanced non-small-cell lung cancer and wild-type EGFR tumours (TAILOR): a randomised controlled trial. Lancet Oncol 2013;14:981988.

-42 Costa DB, Halmos B, Kumar A, Schumer ST, Huberman MS, Boggon TJ, Tenen DG, Kobayashi S: BIM mediates EGFR tyrosine kinase inhibitor-induced apoptosis in lung cancers with oncogenic EGFR mutations. PLoS Med 2007;4:1669-1679; discussion 1680.
43 Cragg MS, Kuroda J, Puthalakath H, Huang DC, Strasser A: Gefitinib-induced killing of NSCLC cell lines expressing mutant EGFR requires BIM and can be enhanced by $\mathrm{BH} 3 \mathrm{mi}-$ metics. PLoS Med 2007;4:1681-1689; discussion 1690.

-44 Gong Y, Somwar R, Politi K, Balak M, Chmielecki J, Jiang X, Pao W: Induction of BIM is essential for apoptosis triggered by EGFR kinase inhibitors in mutant EGFR-dependent lung adenocarcinomas. PLoS Med 2007;4:e294.

45 Sharma SV, Bell DW, Settleman J, Haber DA: Epidermal growth factor receptor mutations in lung cancer. Nat Rev Cancer 2007;7:169181.

46 Arcila ME, Nafa K, Chaft JE, Rekhtman N, Lau C, Reva BA, Zakowski MF, Kris MG, Ladanyi M: EGFR exon 20 insertion mutations in lung adenocarcinomas: prevalence, molecular heterogeneity, and clinicopathologic characteristics. Mol Cancer Ther 2013; 12:220-229.

47 Inukai M, Toyooka S, Ito S, Asano H, Ichihara S, Soh J, Suehisa H, Ouchida M, Aoe K, Aoe M, Kiura K, Shimizu N, Date H: Presence of epidermal growth factor receptor gene T790M mutation as a minor clone in nonsmall cell lung cancer. Cancer Res 2006;66: 7854-7858.

48 Su KY, Chen HY, Li KC, Kuo ML, Yang JC, Chan WK, Ho BC, Chang GC, Shih JY, Yu SL, Yang PC: Pretreatment epidermal growth factor receptor (EGFR) T790M mutation predicts shorter EGFR tyrosine kinase inhibitor response duration in patients with non-smallcell lung cancer. J Clin Oncol 2012;30:433440.

49 Jackman D, Pao W, Riely GJ, Engelman JA, Kris MG, Janne PA, Lynch T, Johnson BE, Miller VA: Clinical definition of acquired resistance to epidermal growth factor receptor tyrosine kinase inhibitors in non-small-cell lung cancer. J Clin Oncol 2010;28:357-360.

50 Engelman JA, Zejnullahu K, Mitsudomi T, Song Y, Hyland C, Park JO, Lindeman N, Gale CM, Zhao X, Christensen J, Kosaka T, Holmes AJ, Rogers AM, Cappuzzo F, Mok T, Lee C, Johnson BE, Cantley LC, Janne PA: MET amplification leads to gefitinib resistance in lung cancer by activating ERBB3 signaling. Science 2007;316:1039-1043.

-51 Bean J, Brennan C, Shih JY, Riely G, Viale A, Wang L, Chitale D, Motoi N, Szoke J, Broderick S, Balak M, Chang WC, Yu CJ, Gazdar A, Pass H, Rusch V, Gerald W, Huang SF, Yang PC, Miller V, Ladanyi M, Yang CH, Pao W: MET amplification occurs with or without T790M mutations in EGFR mutant lung tumors with acquired resistance to gefitinib or erlotinib. Proc Natl Acad Sci USA 2007;104: 20932-20937.
52 Yu HA, Arcila ME, Rekhtman N, Sima CS, Zakowski MF, Pao W, Kris MG, Miller VA, Ladanyi M, Riely GJ: Analysis of tumor specimens at the time of acquired resistance to EGFR-TKI therapy in 155 patients with EGFR-mutant lung cancers. Clin Cancer Res 2013;19:2240-2247.

53 Takezawa K, Pirazzoli V, Arcila ME, Nebhan CA, Song X, de Stanchina E, Ohashi K, Janjigian YY, Spitzler PJ, Melnick MA, Riely GJ, Kris MG, Miller VA, Ladanyi M, Politi K, Pao W: HER2 amplification: a potential mechanism of acquired resistance to EGFR inhibition in EGFR-mutant lung cancers that lack the second-site EGFRT790M mutation. Cancer Discov 2012;2:922-933.

54 Ohashi K, Sequist LV, Arcila ME, Moran T, Chmielecki J, Lin YL, Pan Y, Wang L, de Stanchina E, Shien K, Aoe K, Toyooka S, Kiura K, Fernandez-Cuesta L, Fidias P, Yang JC, Miller VA, Riely GJ, Kris MG, Engelman JA, Vnencak-Jones CL, Dias-Santagata D, Ladanyi M, Pao W: Lung cancers with acquired resistance to EGFR inhibitors occasionally harbor BRAF gene mutations but lack mutations in KRAS, NRAS, or MEK1. Proc Natl Acad Sci USA 2012;109:E2127E2133.

55 Sos ML, Koker M, Weir BA, Heynck S, Rabinovsky R, Zander T, Seeger JM, Weiss J, Fischer F, Frommolt P, Michel K, Peifer M, Mermel C, Girard L, Peyton M, Gazdar AF, Minna JD, Garraway LA, Kashkar H, Pao W, Meyerson M, Thomas RK: PTEN loss contributes to erlotinib resistance in EGFR-mutant lung cancer by activation of Akt and EGFR. Cancer Res 2009;69:3256-3261.

56 Yamamoto C, Basaki Y, Kawahara A, Nakashima K, Kage M, Izumi H, Kohno K, Uramoto $\mathrm{H}$, Yasumoto K, Kuwano M, Ono M: Loss of PTEN expression by blocking nuclear translocation of EGR1 in gefitinib-resistant lung cancer cells harboring epidermal growth factor receptor-activating mutations. Cancer Res 2010;70:8715-8725.

57 de Bruin EC, Cowell C, Warne PH, Jiang M, Saunders RE, Melnick MA, Gettinger S, Walther Z, Wurtz A, Heynen GJ, Heideman DA, Gomez-Roman J, Garcia-Castano A, Gong Y, Ladanyi M, Varmus H, Bernards R, Smit EF, Politi K, Downward J: Reduced NF1 expression confers resistance to EGFR inhibition in lung cancer. Cancer Discov 2014;4:606-619.

58 Zakowski MF, Ladanyi M, Kris MG; Memorial Sloan-Kettering Cancer Center Lung Cancer OncoGenome Group: EGFR mutations in small-cell lung cancers in patients who have never smoked. N Engl J Med 2006; 355:213-215.

59 Uramoto H, Shimokawa H, Hanagiri T, Kuwano M, Ono M: Expression of selected gene for acquired drug resistance to EGFR-TKI in lung adenocarcinoma. Lung Cancer 2011;73: 361-365. 
-60 Sequist LV, Waltman BA, Dias-Santagata D, Digumarthy S, Turke AB, Fidias P, Bergethon K, Shaw AT, Gettinger S, Cosper AK, Akhavanfard S, Heist RS, Temel J, Christensen JG, Wain JC, Lynch TJ, Vernovsky K, Mark EJ, Lanuti M, Iafrate AJ, Mino-Kenudson M, Engelman JA: Genotypic and histological evolution of lung cancers acquiring resistance to EGFR inhibitors. Sci Transl Med 2011;3: $75 \mathrm{ra26.}$

-61 Yao Z, Fenoglio S, Gao DC, Camiolo M, Stiles B, Lindsted T, Schlederer M, Johns C, Altorki N, Mittal V, Kenner L, Sordella R: TGF-beta IL-6 axis mediates selective and adaptive mechanisms of resistance to molecular targeted therapy in lung cancer. Proc Natl Acad Sci USA 2010;107:15535-15540.

-62 Xie M, Zhang L, He CS, Xu F, Liu JL, Hu ZH, Zhao LP, Tian Y: Activation of Notch-1 enhances epithelial-mesenchymal transition in gefitinib-acquired resistant lung cancer cells. J Cell Biochem 2012;113:1501-1513.

-63 Zhang Z, Lee JC, Lin L, Olivas V, Au V, LaFramboise T, Abdel-Rahman M, Wang X, Levine AD, Rho JK, Choi YJ, Choi CM, Kim SW, Jang SJ, Park YS, Kim WS, Lee DH, Lee JS, Miller VA, Arcila M, Ladanyi M, Moonsamy P, Sawyers C, Boggon TJ, Ma PC, Costa C, Taron M, Rosell R, Halmos B, Bivona TG: Activation of the AXL kinase causes resistance to EGFR-targeted therapy in lung cancer. Nat Genet 2012;44:852-860.

64 Taniguchi K, Okami J, Kodama K, Higashiyama M, Kato K: Intratumor heterogeneity of epidermal growth factor receptor mutations in lung cancer and its correlation to the response to gefitinib. Cancer Sci 2008;99:929935.

65 Pao W, Miller VA, Politi KA, Riely GJ, Somwar R, Zakowski MF, Kris MG, Varmus H: Acquired resistance of lung adenocarcinomas to gefitinib or erlotinib is associated with a second mutation in the EGFR kinase domain. PLoS Med 2005;2:e73.

66 Yun CH, Mengwasser KE, Toms AV, Woo MS, Greulich H, Wong KK, Meyerson M, Eck MJ: The T790M mutation in EGFR kinase causes drug resistance by increasing the affinity for ATP. Proc Natl Acad Sci USA 2008; 105:2070-2075.

-67 Ercan D, Zejnullahu K, Yonesaka K, Xiao Y, Capelletti M, Rogers A, Lifshits E, Brown A, Lee C, Christensen JG, Kwiatkowski DJ, Engelman JA, Janne PA: Amplification of EGFR T790M causes resistance to an irreversible EGFR inhibitor. Oncogene 2010;29:23462356.

-68 Azam M, Seeliger MA, Gray NS, Kuriyan J, Daley GQ: Activation of tyrosine kinases by mutation of the gatekeeper threonine. Nat Struct Mol Biol 2008;15:1109-1118.

-69 Gorre ME, Mohammed M, Ellwood K, Hsu N, Paquette R, Rao PN, Sawyers CL: Clinical resistance to STI-571 cancer therapy caused by BCR-ABL gene mutation or amplification. Science 2001;293:876-880.
70 Tamborini E, Bonadiman L, Greco A, Albertini V, Negri T, Gronchi A, Bertulli R, Colecchia M, Casali PG, Pierotti MA, Pilotti S: A new mutation in the KIT ATP pocket causes acquired resistance to imatinib in a gastrointestinal stromal tumor patient. Gastroenterology 2004;127:294-299.

71 Choi YL, Soda M, Yamashita Y, Ueno T, Takashima J, Nakajima T, Yatabe Y, Takeuchi K, Hamada T, Haruta H, Ishikawa Y, Kimura H, Mitsudomi T, Tanio Y, Mano H; ALK Lung Cancer Study Group: EML4-ALK mutations in lung cancer that confer resistance to ALK inhibitors. N Engl J Med 2010;363:17341739.

-72 Balak MN, Gong Y, Riely GJ, Somwar R, Li AR, Zakowski MF, Chiang A, Yang G, Ouerfelli O, Kris MG, Ladanyi M, Miller VA, Pao W: Novel D761Y and common secondary T790M mutations in epidermal growth factor receptor-mutant lung adenocarcinomas with acquired resistance to kinase inhibitors. Clin Cancer Res 2006;12:6494-6501.

73 Bean J, Riely GJ, Balak M, Marks JL, Ladanyi M, Miller VA, Pao W: Acquired resistance to epidermal growth factor receptor kinase inhibitors associated with a novel T854A mutation in a patient with EGFR-mutant lung adenocarcinoma. Clin Cancer Res 2008; 14: 7519-7525.

74 Nguyen KS, Kobayashi S, Costa DB: Acquired resistance to epidermal growth factor receptor tyrosine kinase inhibitors in non-smallcell lung cancers dependent on the epidermal growth factor receptor pathway. Clin Lung Cancer 2009; 10:281-289.

75 Zhou BB, Peyton M, He B, Liu C, Girard L, Caudler E, Lo Y, Baribaud F, Mikami I, Reguart N, Yang G, Li Y, Yao W, Vaddi K, Gazdar AF, Friedman SM, Jablons DM, Newton RC, Fridman JS, Minna JD, Scherle PA: Targeting ADAM-mediated ligand cleavage to inhibit HER3 and EGFR pathways in nonsmall cell lung cancer. Cancer Cell 2006;10: 39-50.

76 Yonesaka K, Hirotani K, Kawakami H, Takeda M, Kaneda H, Sakai K, Okamoto I, Nishio K, Janne PA, Nakagawa K: Anti-HER3 monoclonal antibody patritumab sensitizes refractory non-small cell lung cancer to the epidermal growth factor receptor inhibitor erlotinib. Oncogene 2015, DOI: 10.1038/ onc.2015.142.

77 Ludovini V, Bellezza G, Pistola L, Bianconi F, Di Carlo L, Sidoni A, Semeraro A, Del Sordo R, Tofanetti FR, Mameli MG, Daddi G, Cavaliere A, Tonato M, Crino L: High coexpression of both insulin-like growth factor receptor-1 (IGFR-1) and epidermal growth factor receptor (EGFR) is associated with shorter disease-free survival in resected non-smallcell lung cancer patients. Ann Oncol 2009;20: 842-849.
8 Peled N, Wynes MW, Ikeda N, Ohira T, Yoshida K, Qian J, Ilouze M, Brenner R, Kato Y, Mascaux C, Hirsch FR: Insulin-like growth factor-1 receptor (IGF-1R) as a biomarker for resistance to the tyrosine kinase inhibitor gefitinib in non-small cell lung cancer. Cell Oncol (Dordr) 2013;36:277-288.

79 Ware KE, Hinz TK, Kleczko E, Singleton KR, Marek LA, Helfrich BA, Cummings CT, Graham DK, Astling D, Tan AC, Heasley LE: A mechanism of resistance to gefitinib mediated by cellular reprogramming and the acquisition of an FGF2-FGFR1 autocrine growth loop. Oncogenesis 2013;2:e39.

80 Terai H, Soejima K, Yasuda H, Nakayama S, Hamamoto J, Arai D, Ishioka K, Ohgino K, Ikemura S, Sato T, Yoda S, Satomi R, Naoki K, Betsuyaku T: Activation of the FGF2-FGFR1 autocrine pathway: a novel mechanism of acquired resistance to gefitinib in NSCLC. Mol Cancer Res 2013;11:759-767.

81 Scagliotti G, von Pawel J, Novello S, Ramlau R, Favaretto A, Barlesi F, Akerley W, Orlov S, Santoro A, Spigel D, Hirsh V, Shepherd FA, Sequist LV, Sandler A, Ross JS, Wang Q, von Roemeling R, Shuster D, Schwartz B: Phase III multinational, randomized, double-blind, placebo-controlled study of tivantinib (ARQ 197) plus erlotinib versus erlotinib alone in previously treated patients with locally advanced or metastatic nonsquamous nonsmall-cell lung cancer. J Clin Oncol 2015;33: 2667-2674.

82 Sierke SL, Cheng K, Kim HH, Koland JG: Biochemical characterization of the protein tyrosine kinase homology domain of the ErbB3 (HER3) receptor protein. Biochem J 1997; 322:757-763.

83 Wallasch C, Weiss FU, Niederfellner G, Jallal $B$, Issing $W$, Ullrich A: Heregulin-dependent regulation of HER2/neu oncogenic signaling by heterodimerization with HER3. EMBO J 1995; 14:4267-4275.

84 Tzahar E, Waterman H, Chen X, Levkowitz G, Karunagaran D, Lavi S, Ratzkin BJ, Yarden Y: A hierarchical network of interreceptor interactions determines signal transduction by Neu differentiation factor/neuregulin and epidermal growth factor. Mol Cell Biol 1996; 16:5276-5287.

85 Gollamudi M, Nethery D, Liu J, Kern JA: Autocrine activation of ErbB2/ErbB3 receptor complex by NRG-1 in non-small cell lung cancer cell lines. Lung Cancer 2004;43:135143.

86 Nishio M, Horiike A, Murakami H, Yamamoto N, Kaneda H, Nakagawa K, Horinouchi H, Nagashima M, Sekiguchi M, Tamura T: Phase I study of the HER3-targeted antibody patritumab (U3-1287) combined with erlotinib in Japanese patients with nonsmall cell lung cancer. Lung Cancer 2015;88: 275-281.
Drug Resistance to EGFR Inhibitors in Lung Cancer
Chemotherapy 2015-16;61:223-235 DOI: $10.1159 / 000443368$ 
87 Cappuzzo F, Toschi L, Tallini G, Ceresoli GL, Domenichini I, Bartolini S, Finocchiaro G, Magrini E, Metro G, Cancellieri A, Trisolini R, Crino L, Bunn PA Jr, Santoro A, Franklin WA, Varella-Garcia M, Hirsch FR: Insulin-like growth factor receptor 1 (IGFR1 ) is significantly associated with longer survival in non-small-cell lung cancer patients treated with gefitinib. Ann Oncol 2006; 17: 1120-1127.

-88 Stambolic V, Suzuki A, de la Pompa JL, Brothers GM, Mirtsos C, Sasaki T, Ruland J, Penninger JM, Siderovski DP, Mak TW: Negative regulation of $\mathrm{PKB} /$ Akt-dependent cell survival by the tumor suppressor PTEN. Cell 1998;95:29-39.

89 Bollag G, McCormick F: Differential regulation of rasGAP and neurofibromatosis gene product activities. Nature 1991;351:576579.

90 Maertens O, Cichowski K: Paths of resistance to EGFR inhibitors: is NF enough? Cancer Discov 2014;4:519-521.

-91 Niederst MJ, Sequist LV, Poirier JT, et al: RB loss in resistant EGFR mutant lung adenocarcinomas that transform to small-cell lung cancer. Nat Commun 2015;6:6377.

92 George J, Lim JS, Jang SJ, et al: Comprehensive genomic profiles of small cell lung cancer. Nature 2015;524:47-53.

\$3 Oser MG, Niederst MJ, Sequist LV, Engelman JA: Transformation from non-smallcell lung cancer to small-cell lung cancer: molecular drivers and cells of origin. Lancet Oncol 2015;16:e165-e172.

-94 Lin C, Song H, Huang C, Yao E, Gacayan R, Xu SM, Chuang PT: Alveolar type II cells possess the capability of initiating lung tumor development. PLoS One 2012;7:e53817.

$\$ 95$ Kalluri R, Weinberg RA: The basics of epithelial-mesenchymal transition. J Clin Invest 2009;119:1420-1428.

96 Phuchareon J, McCormick F, Eisele DW, Tetsu O: EGFR inhibition evokes innate drug resistance in lung cancer cells by preventing Akt activity and thus inactivating Ets-1 function. Proc Natl Acad Sci USA 2015;112:E3855-E3863.

-97 Tetsu O, Phuchareon J, Eisele DW, Hangauer MJ, McCormick F: AKT inactivation causes persistent drug tolerance to EGFR inhibitors. Pharmacol Res 2015;102:132-137.

98 Phuchareon J, McCormick F, Eisele DW, Tetsu O: EGFR inhibition generates drugtolerant persister cells by blocking AKT activity. Cancer Cell Microenviron 2015; 2:e1045.

-99 Aguirre-Ghiso JA: Models, mechanisms and clinical evidence for cancer dormancy. Nat Rev Cancer 2007;7:834-846.

-100 Sosa MS, Bragado P, Aguirre-Ghiso JA: Mechanisms of disseminated cancer cell dormancy: an awakening field. Nat Rev Cancer 2014;14:611-622.

101 Yeh AC, Ramaswamy S: Mechanisms of cancer cell dormancy - another hallmark of cancer? Cancer Res 2015;75:5014-5022.
102 Sharma SV, Lee DY, Li B, Quinlan MP, Takahashi F, Maheswaran S, McDermott U, Azizian N, Zou L, Fischbach MA, Wong KK, Brandstetter K, Wittner B, Ramaswamy S, Classon M, Settleman J: A chromatin-mediated reversible drug-tolerant state in cancer cell subpopulations. Cell 2010;141:69-80.

103 Hobby GL, Meyer K, Chaffee E: Observations on the mechanism of action of penicillin. Proc Soc Exp Biol NY 1942;50:281-285.

104 Zhang Y: Persisters, persistent infections and the Yin-Yang model. Emerg Microbes Infect 2014;3:e3.

105 Bigger JW: Treatment of staphylococcal infections with penicillin by intermittent sterilisation. Lancet 1944;244:497-500.

106 Tetsu O, Eisele DW, McCormick F: Resistance to EGFR-targeted therapy by Ets- 1 inactivation. Cell Cycle 2015;14:3211-3212.

-107 Tetsu O, Phuchareon J, Eisele DW, McCormick F: ETS1 inactivation causes innate drug resistance to EGFR inhibitors. Mol Cell Oncol 2015, DOI: 10.1080/23723556.2015. 1078924.

108 Watanabe S, Tanaka J, Ota T, Kondo R, Tanaka H, Kagamu H, Ichikawa K, Koshio J, Baba J, Miyabayashi T, Narita I, Yoshizawa $\mathrm{H}$ : Clinical responses to EGFR-tyrosine kinase inhibitor retreatment in non-small cell lung cancer patients who benefited from prior effective gefitinib therapy: a retrospective analysis. BMC Cancer 2011;11:1.

109 Reid A, Vidal L, Shaw H, de Bono J: Dual inhibition of ErbB1 (EGFR/HER1) and ErbB2 (HER2/neu). Eur J Cancer 2007;43: 481-489.

110 Engelman JA, Zejnullahu K, Gale CM, Lifshits E, Gonzales AJ, Shimamura T, Zhao F, Vincent PW, Naumov GN, Bradner JE, Althaus IW, Gandhi L, Shapiro GI, Nelson JM, Heymach JV, Meyerson M, Wong KK, Janne PA: PF00299804, an irreversible pan-ERBB inhibitor, is effective in lung cancer models with EGFR and ERBB2 mutations that are resistant to gefitinib. Cancer Res 2007;67: 11924-11932.

111 Rabindran SK, Discafani CM, Rosfjord EC, Baxter M, Floyd MB, Golas J, Hallett WA, Johnson BD, Nilakantan R, Overbeek E, Reich MF, Shen R, Shi X, Tsou HR, Wang YF, Wissner A: Antitumor activity of HKI272 , an orally active, irreversible inhibitor of the HER-2 tyrosine kinase. Cancer Res 2004; 64:3958-3965.

-112 Kwak EL, Sordella R, Bell DW, Godin-Heymann N, Okimoto RA, Brannigan BW, Harris PL, Driscoll DR, Fidias P, Lynch TJ, Rabindran SK, McGinnis JP, Wissner A, Sharma SV, Isselbacher KJ, Settleman J, Haber DA: Irreversible inhibitors of the EGF receptor may circumvent acquired resistance to gefitinib. Proc Natl Acad Sci USA 2005;102: 7665-7670.

\section{(1)}

13 Engelman JA, Zejnullahu K, Gale CM, Lifshits E, Gonzales AJ, Shimamura T, Zhao F, Vincent PW, Naumov GN, Bradner JE, Althaus IW, Gandhi L, Shapiro GI, Nelson JM, Heymach JV, Meyerson M, Wong KK, Janne PA: PF00299804, an irreversible pan-ERBB inhibitor, is effective in lung cancer models with EGFR and ERBB2 mutations that are resistant to gefitinib. Cancer Res 2007;67: 11924-11932.

114 Miller VA, Hirsh V, Cadranel J, Chen YM, Park K, Kim SW, Zhou C, Su WC, Wang M, Sun Y, Heo DS, Crino L, Tan EH, Chao TY, Shahidi M, Cong XJ, Lorence RM, Yang JC: Afatinib versus placebo for patients with advanced, metastatic non-small-cell lung cancer after failure of erlotinib, gefitinib, or both, and one or two lines of chemotherapy (LUX-Lung 1): a phase $2 \mathrm{~b} / 3$ randomised trial. Lancet Oncol 2012;13:528-538.

115 Ellis PM, Shepherd FA, Millward M, et al; NCIC CTG; Australasian Lung Cancer Trials Group; NCI Naples Clinical Trials Unit: Dacomitinib compared with placebo in pretreated patients with advanced or metastatic non-small-cell lung cancer (NCIC CTG BR.26): a double-blind, randomised, phase 3 trial. Lancet Oncol 2014;15:1379-1388.

116 Sequist LV, Besse B, Lynch TJ, Miller VA, Wong KK, Gitlitz B, Eaton K, Zacharchuk C, Freyman A, Powell C, Ananthakrishnan R, Quinn S, Soria JC: Neratinib, an irreversible pan-ErbB receptor tyrosine kinase inhibitor: results of a phase II trial in patients with advanced non-small-cell lung cancer. J Clin Oncol 2010;28:30763083.

117 Cross DA, Ashton SE, Ghiorghiu S, Eberlein C, Nebhan CA, Spitzler PJ, Orme JP, Finlay MR, Ward RA, Mellor MJ, Hughes G, Rahi A, Jacobs VN, Red Brewer M, Ichihara E, Sun J, Jin H, Ballard P, Al-Kadhimi K, Rowlinson R, Klinowska T, Richmond GH, Cantarini M, Kim DW, Ranson MR, Pao W: AZD9291, an irreversible EGFR TKI, overcomes T790M-mediated resistance to EGFR inhibitors in lung cancer. Cancer Discov 2014;4:1046-1061.

-118 Walter AO, Sjin RT, Haringsma HJ, Ohashi K, Sun J, Lee K, Dubrovskiy A, Labenski M, Zhu Z, Wang Z, Sheets M, St Martin T, Karp R, van Kalken D, Chaturvedi P, Niu D, Nacht M, Petter RC, Westlin W, Lin K, Jaw-Tsai S, Raponi M, Van Dyke T, Etter J, Weaver Z, Pao W, Singh J, Simmons AD, Harding TC, Allen A: Discovery of a mutant-selective covalent inhibitor of EGFR that overcomes T790M-mediated resistance in NSCLC. Cancer Discov 2013;3:1404-1415.

119 Sakuma Y, Yamazaki Y, Nakamura Y, Yoshihara M, Matsukuma S, Nakayama H, Yokose T, Kameda Y, Koizume S, Miyagi Y: WZ4002, a third-generation EGFR inhibitor, can overcome anoikis resistance in EGFR-mutant lung adenocarcinomas more efficiently than Src inhibitors. Lab Invest 2012;92:371-383. 
120 Janne PA, Yang JC, Kim DW, Planchard D, Ohe Y, Ramalingam SS, Ahn MJ, Kim SW, Su WC, Horn L, Haggstrom D, Felip E, Kim $\mathrm{JH}$, Frewer P, Cantarini M, Brown $\mathrm{KH}$, Dickinson PA, Ghiorghiu S, Ranson M: AZD9291 in EGFR inhibitor-resistant nonsmall-cell lung cancer. N Engl J Med 2015; 372:1689-1699.

121 Sequist LV, Soria JC, Goldman JW, et al: Rociletinib in EGFR-mutated non-small-cell lung cancer. N Engl J Med 2015;372:17001709.

122 Piotrowska Z, Niederst MJ, Karlovich CA, Wakelee HA, Neal JW, Mino-Kenudson M, Fulton L, Hata AN, Lockerman EL, Kalsy A, Digumarthy S, Muzikansky A, Raponi M, Garcia AR, Mulvey HE, Parks MK, DiCecca RH, Dias-Santagata D, Iafrate AJ, Shaw AT, Allen AR, Engelman JA, Sequist LV: Heterogeneity underlies the emergence of EGFRT790 wild-type clones following treatment of T790M-positive cancers with a third-generation EGFR inhibitor. Cancer Discov 2015;5:713-722.
123 Eberlein CA, Stetson D, Markovets AA, AlKadhimi KJ, Lai Z, Fisher PR, Meador CB, Spitzler P, Ichihara E, Ross SJ, Ahdesmaki MJ, Ahmed A, Ratcliffe LE, O'Brien EL, Barnes CH, Brown H, Smith PD, Dry JR, Beran G, Thress KS, Dougherty B, Pao W, Cross DA: Acquired resistance to the mutant-selective EGFR inhibitor AZD9291 is associated with increased dependence on RAS signaling in preclinical models. Cancer Res 2015;75:2489-2500.

124 Thress KS, Paweletz CP, Felip E, Cho BC, Stetson D, Dougherty B, Lai Z, Markovets A, Vivancos A, Kuang Y, Ercan D, Matthews SE, Cantarini M, Barrett JC, Janne PA, Oxnard GR: Acquired EGFR C797S mutation mediates resistance to AZD9291 in nonsmall cell lung cancer harboring EGFR T790M. Nat Med 2015;21:560-562.

125 Ercan D, Choi HG, Yun CH, Capelletti M, Xie T, Eck MJ, Gray NS, Janne PA: EGFR mutations and resistance to irreversible pyrimidine-based EGFR inhibitors. Clin Cancer Res 2015;21:3913-3923.

126 Planchard D, Loriot Y, André F, Gobert A, Auger N, Lacroix L, Soria JC: EGFR-independent mechanisms of acquired resistance to AZD9291 in EGFR T790M-positive NSCLC patients. Ann Oncol 2015;26:20732078.
27 Ayeni D, Politi K, Goldberg SB: Emerging agents and new mutations in EGFR-mutant lung cancer. Clin Cancer Res 2015;21:38183820.

128 Witta SE, Jotte RM, Konduri K, Neubauer MA, Spira AI, Ruxer RL, Varella-Garcia M, Bunn PA Jr, Hirsch FR: Randomized phase II trial of erlotinib with and without entinostat in patients with advanced non-smallcell lung cancer who progressed on prior chemotherapy. J Clin Oncol 2012;30:22482255.

129 Tricker EM, Xu C, Uddin S, Capelletti M, Ercan D, Ogino A, Pratilas CA, Rosen N, Gray NS, Wong KK, Janne PA: Combined EGFR/MEK inhibition prevents the emergence of resistance in EGFR-mutant lung cancer. Cancer Discov 2015;5:960-971.

130 Corcoran RB, Ebi H, Turke AB, Coffee EM, Nishino M, Cogdill AP, Brown RD, Della Pelle P, Dias-Santagata D, Hung KE, Flaherty KT, Piris A, Wargo JA, Settleman J, Mino-Kenudson M, Engelman JA: EGFRmediated re-activation of MAPK signaling contributes to insensitivity of BRAF mutant colorectal cancers to RAF inhibition with vemurafenib. Cancer Discov 2012;2:227-235.

131 Collins FS, Varmus H: A new initiative on precision medicine. N Engl J Med 2015;372: 793-795. 